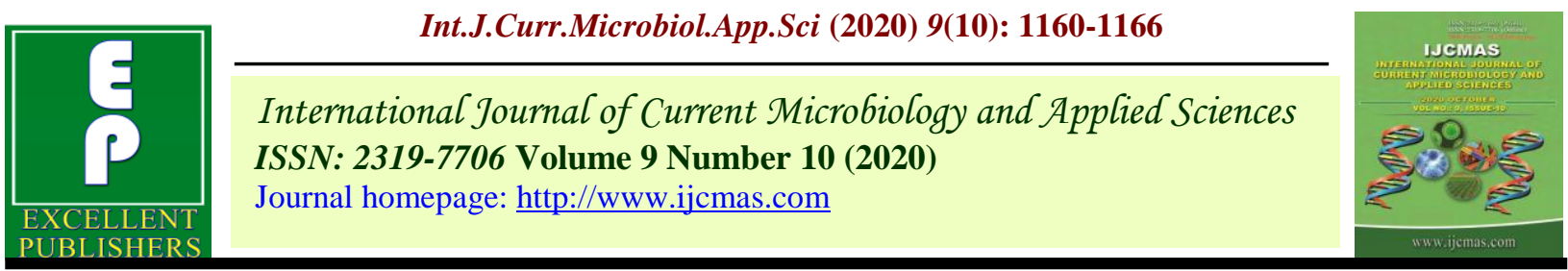

Review Article

https://doi.org/10.20546/ijcmas.2020.910.139

\title{
A Review on Effect of Integrated Nutrient Management on Paddy
}

\author{
Bhanuwanti* and Pratima Vaidya \\ Maharishi Markandeshwar University, Ambala, India \\ *Corresponding author
}

\begin{abstract}
A B S T R A C T
Keywords

Integrated Nutrient

Management

(INM), Paddy

Article Info

Accepted:

10 September 2020

Available Online:

10 October 2020

Integrated Nutrient Management (INM) is an agronomic practice in which both organic and inorganic sources of fertilizers are used. The main aim of INM is to minimize the use of chemical fertilizers. It can reduce environmental pollution and help in maintaining soil fertility by fulfilling the plant nutrient requirement. It also helps in maximizing profitability and reducing environmental hazards. In plants, roots control nutrient conversions, microbial activity and plants absorb nutrients. Due to this, INM practice is applied to the root zone. It also enhances microbial activity. This strategy is essential to plummet the disease infestation through managing the level of potassium, nitrogen and other essential elements. The application of organic manure with recommended dose of fertilizers is useful to enhance soil organic carbon and productivity. INM enhances the profitability of farmer by reducing the cost of cultivation. However, many farmers face obstacles in obtaining organic manures because they have limited knowledge of organic waste recycling to produce high-quality compost. Moreover, biotic and abiotic factors, poor tillage, unavailability of extension services are some other problems due to which farmers are unable to follow integrated nutrient management. There are various benefits of using INM such as soil conservation, nutrient management, and restoration of ecological balance. Therefore, the government should focus to promote INM strategy to enhance farming yield with minimum deterioration of natural resources.
\end{abstract}

\section{Introduction}

Global population is increasing day by day. In order to fulfill the demand of growing population, global food production needs to be enhanced at least by $70 \%$ by 2050 (Bruinsma, 2009).Considering limited land resources, enhancing agriculture productivity is the only factor to fulfill the growing need for food (FAO, 2009). There is a need to grow agriculture to accomplish this target. Two main factors which influence the crop growth and yield are soil nutrient content and nutrients, which are required for the crop (Ali et al., 2010). In the present scenario, many farmers applies excessive dose of chemicals in their paddy field which increases the overall cost and reduces the profit. Inorganic fertilizers help to increase the yield, but injudicious fertilizer application also have additional drawbacks such as micronutrient deficiency, soil and water contamination, and alteration in soil physico-chemical properties (Selim, 2018). Some chemical fertilizers also 
results in buildup of heavy metal such as $\mathrm{Cd}$, $\mathrm{Pb}$ etc. in the soil. To obtain desired crop productivity the usage of inorganic fertilizers must be reduced. Combined use of natural and chemical fertilizers is the only solution for all the problems. Organic manures such as animal and plant waste products, composts, recycled waste organic material, and inorganic fertilizers such as urea, DAP, etc. can be used together to meet the objective of enhancing yield with minimum environmental degradation (Zhang et al., 2012). Integrated Nutrient Management (INM) plays a crucial role in sustainable production system by supplying both micro and macronutrients in appropriate quantity at low cost. INM is the main key for proper management and utilization of agriculture residues (Ogunwale et al., 2002).

Definition of INM: Integrated nutrient management is the combined use of both organic and inorganic fertilizers which reduces the usage of chemicals in agriculture. It fills the gap between the nutrient requirement of the crop and fertilizer inputs. INM also plays significant role in improving soil fertility. Organic matter addition through organic manures enhances nutrient cycling and improves physical, chemical and biological properties of soil. INM practices elevate the yield and enhance the overall income of farmer. Apart from this, it also lower the environmental contamination (Zhang et al., 2014).Thus, INM is a technique of improving soil health at a low cost.

\section{Objectives of INM}

The basic aim of INM is to maintain a profitable yield for a longtime without diminishing the soil physico-chemical properties and environmental quality. It guides farmers towards eco-friendly techniques so that every citizen can obtain a good quality of food without any contamination.
The main strategies of INM are:

Rational use of both organic and chemical fertilizers is necessary as it lowers the cost of cultivation and environmental contamination.

INM practices should be chosen according to the local farming system. Soil characteristics, sand, silt, and clay composition, availability of water, insects and disease infestation, implements, and climatic conditions must be given due consideration during planning.

Nutrients must be applied according to crop demand.

Control nutrient conversions and microbial activity (Selim and Imhoff, 2020).

\section{INM in Paddy}

INM is the best practice in which plant takes nutrient through organic and inorganic fertilizer. These are helpful to maintain ecological balance and to enhance soil fertility. Apart from this, it is used to improve rice productivity. To achieve maximum crop productivity the combination of both natural and manmade sources is imperative (Gruhan et al., 2000; Mahajan et al., 2008).

Four management practices are necessary to regulate INM in paddy are:

Need-based fertilizer use

Apply accurate amount of fertilizer

Correct placement

Right time for fertilization

\section{Smart nitrogen fertilizer management}

The application of nitrogen influences the number of tillers, which affects rice grain yield. In rice, doses of nitrogen are highly dependent on soil. To achieve equal grain yield, clay soil needs $40-60 \mathrm{~kg}$ more nitrogen 
than silty loam soil. There are various sources of nitrogen fertilizers such as neem coated, sulphur coated, polyamine coated. These sources play a vital role to enhance the yield of rice under tough soil and climate condition (Fageria et al., 2010).

\section{Smart phosphorus fertilizer management}

There are various functions of phosphorus in rice. Phosphorus is used for energy storage in plants and transfers this energy to different parts of plants. Therefore, the right dose of phosphorus is necessary. Besides this, in rice, phosphorus is responsible for early maturity, straw strength, crop quality, and disease resistance. In industrial agriculture, at the grain filling stage, the foliar application is necessary (Savant et al., 1982).

\section{Smart potassium fertilizer management}

If potassium is not available in sufficient amount it will leads to occurrences of disease like, kernel smut, stem and sheath rot in rice plant. Therefore, to protect plant from diseases recommended dose via foliage produces better result.

\section{Smart micronutrients management in rice growth}

There are certain micronutrients, which are essential for paddy crop such as zinc, iron and manganese. In rice production, micronutrient deficiencies are becoming more common. In high $\mathrm{pH}$ soils, deficiency of $\mathrm{Zn}$ and Fe are very common. Green manuring is also helpful to alleviate the deficiency of micronutrients (Fageria et al., 2008).

\section{Beneficial plant nutrient management and rice growth}

Silicon is observed as a beneficial element beneficial for rice growth. Rice is considered as Si-accumulator species. In some areas of
United States, application of Si-amendments has shown to be beneficial for rice growth, yield and pest resistance (Gruhan et al., 2000).

\section{Effect of INM on Diseases in Paddy}

INM is helpful to reduce the disease infestation by managing the level of nitrogen, phosphorus, potassium, and other essential elements. In general, the overall health of plants can also have an impact on disease occurrence (Nas et al., 2012).

\section{Role of organic fertilizers and biofertilizers on rice disease}

If straw compost is mixed with consortia of biofertilizers, it remediates and improves soil health. It also increases rice productivity in a sustainable manner (Simarmata et al., 2015). Additionally, the biodiversity of beneficial microbes is raised by straw bacteria and promote induced systemic resistance (ISR). ISR creates an important mechanism in selected plants through this whole plant body to defend itself from pathogens and insect herbivores (Gaind et al., 2011).

An experiment was conducted to study about the effect of composted straw, consortia of biofertilizers, and combination of consortia of biofertilizers with Trichoderma species on the intensity of brown spot (Helminthosporium oryzae), narrow brown spot (Cercospora janseana), sheath rice blight (Rhizoctonia solani), and bacterial leaf blight diseases (Xanthomonas oryzae) of rice at 7 weeks after transplanting(Simarmata et al., 2011).

They concluded that by applying $400 \mathrm{~g}$ per ha of consortia of biofertilizers or $400 \mathrm{~g}$ consortia of biofertilizers combined with Trichoderma combined with 2.5-7.5 ton per ha of composted straw (bioameliorant) had increased the ISR and rice productivity. 
Intensity of brown spot diseases reduced from 16.7 to $3.3-8.0 \%$, narrow brown spot diseases from $20 \%$ to $4-10 \%$, sheath rice blight from $24 \%$ to $2.7-4.7 \%$ at 7 weeks after transplanting (Simarmata et al., 2011).

\section{Role of inorganic fertilizers}

Nitrogen deficiency in paddy leads to chlorosis in older leaves, necrosis and retarded growth of plants. Excessive application of nitrogen increases the disease and insect susceptibility, weakens the stem and led to patchy appearance of the crop. However, some other diseases that occur due to excessive nitrogen fertilizer such as bacterial leaf blight (BLB), bacterial leaf streak, false smut, leaf blast, sheath blast, and sheath rot, etc. During monsoon season, BLB is even worst. Due to this, in monsoon season application of nitrogen should be lower than in dry season. Therefore, accurate amount of nitrogen is necessary to avoid the problems in paddy. Accurate amount of $\mathrm{N}$ leads to better growth and keeps plant healthy and prevents from injury.

Phosphorus regulates the root and tissue development, enhance flowering under cool temperature and thus maximizes the paddy yield and quality. There are several other problems, which can be seen if phosphorus is applied insufficiently such as Fe toxicity at low pH, Zn deficiency, Fe deficiency and soil becomes saline. Phosphorus plays a crucial role to minimize the incidence of BLB, but on the other hand, it encourages other diseases in rice such as leaf blast and sheath blight (Nas et al., 2012). Excessive use of phosphate fertilizer hampers the growth and development of paddy.

Excessive potassium increases the quantity of inhibitory amino acid. It also affects proper functioning of stomata, enhances grain weight and prevents disease incidences. Deficiency of potassium leads to necrosis, dark green appearance of plants, yellowing of leaf margins, curling and wilting of leaves.

\section{Effect of INM on Weeds in Paddy}

Weeds are the major problem in paddy crops because they compete with the main crop for nutrients, water, light and space. Due to this, they hamper the product's quality. In certain cases, it has been observed that crop is damaged fully in critical condition (Gaind et al., 2011). Competition is high in directseeding rice than transplanting (Singh et al., 1992).

A Study was carried out by Singh et al., (2005) to demonstrate the effect of INM approach on weeds in upland rice. They observed that the dry weight of weed is increased remarkably with $100 \%$ recommended dose of nitrogen through FYM. On the contrary, the dry weight of weed was quite low by applying 100\% RDN (Vermicompost). Hence, FYM, which is used in INM, should be well rotten so that the viability of weed seed must be lost during decomposition so that weed infestation is reduced (Rao et al., 2007; Mishra et al., 2008).

\section{Effect of INM on Soil Fertility}

In present scenario, the main reason of low fertile soil is injudicious use of chemical fertilizers (Bhattacharya et al., 2007; Mahanta et al., 2013). If natural resources are applied in combination with recommended dose of fertilizers, it directly elevates soil organic carbon, crop growth and productivity (Jat et al., 2013; Meena et al., 2013). Several studies demonstrated that INM is helpful to improve yield, reduce denitrification losses and leaching; reduces mineralization and enhances fertilizer use efficiency. Overall, it ameliorate the soil health, productivity with 
long-term sustainability of the system (Kumar et al., 2014; Rahman et al., 2013). Judicious use of fertilizers enhances the soil organic carbon significantly. Kumar et al., (2012) observed highest organic carbon in $(50 \%$ RDF (NPK) + 50\% N through FYM), while control was observed with lowest organic carbon. By applying 100\% RDF alone through fertilizers, the availability of N, P and $\mathrm{K}$ increased. The application of manures along with inorganic fertilizers reduces the soil electrical conductivity.

\section{Constraints of INM}

Despite large number of advantages of INM, it is yet to fetch the pace in farmer's field. Because, there are some problems in the progress of integrated nutrient management such as: the unavailability of FYM and biofertilizers; lack of knowledge among poor farmers; availability of organic manure and limited know-how about recycling organic waste to produce high-quality compost. Moreover, biotic and abiotic factors, poor tillage, unavailability of extension services are some other problems due to which farmers are unable to follow integrated nutrient management. Therefore, to curb the problem of low soil productivity there is an urgent need to sustain soil health. Serious efforts should be made to promote integrated nutrient management rationally. So, in order to promote INM government should pay attention to the importance of using organic and inorganic fertilizers altogether and its benefit in conserving soil properties, nutrient balance, and minimizing the environmental impacts (Tirole-padre et al., 2007).

\section{Current status of INM in India}

In this era, farmers mostly rely on manmade chemical fertilizers and have reduced the usage of natural resources drastically. Due to this, the level of organic matter is reducing and soil is facing multi-nutrient deficiencies. Large amount of carbon and micronutrients are available in agricultural and domestic wastes. If these types of wastes are recycled properly, they will cut the rising cost of chemical fertilizers. To adopt INM approach incentives are required to promote the use of organic manure/fertilizers as well as biological sources like biofertilizers.

In India, many initiatives are taken by government of India to enhance agricultural productivity. During $12^{\text {th }}$ plan, National Mission for Sustainable Agriculture (NMSA) in year 2017is executed with the goal to make agriculture more productive. The most important discovery of INM is soil health management (SHM). The primary objective of SHM is promoting INM through:

Judicious use of manmade fertilizers including all the essential nutrients in combination with organic manures and biofertilizers, which is imperative for soil health and productivity.

Soil and fertilizer testing facilities are provided to the farmers for improving soil health.

This component is implemented by State Government., National Centre of Organic Farming (NCOF), Central Fertilizer Quality Control \& Training Institute (CFQC\&TI) and is sanctioned by INM division.

In conclusion the integrated nutrient management has remarkable benefits if farmers use this practice appropriately. Nowa-days, soil fertility is diminished day-by-day because of the excessive use of chemical fertilizers which leads to environmental contamination. In the upcoming years, food security will become the main issue because the soil would not be able to meet the growing food demand. Therefore, to preserve soil 
fertility INM is the best option to protect soil from harmful chemicals. Several studies have revealed the effect of INM on weed reduction, diseases resistance, enhanced economic yield, and soil fertility improvement in paddy. Despite this, the judicious application of mineral and organic fertilization leads to better efficiency, enhance soil-plantmicrobes-environmental sustainability. INM is a very effective method to reuse agriculture or other domestic waste. Many farmers and researchers are focused on INM due to large numbers of advantages, apart from this government has initiated many schemes such as soil health cards through which farmer can check out the soil fertility status.

\section{References}

Ali, A. M., Alam, M. R., Molla, M. S. H., and Islam, F. 2010. Crop productivity asaffectedby fertilizer management options in Boro-T. aman cropping pattern at farmer's fields. Bangladesh Journal of Agricultural Research. 35(2): 287-296.

Bhattacharyya, R., Chandra, S., Singh, R.D., Kundu, S., Srivastva, A.K. and Gupta, H.S. 2007. Long-term farmyard manure application effects on properties of a silty clay Loam soil under irrigated wheatsoybean rotation. Soil \& Tillage Research94:386-396.

Bruinsma, J.2009. The resource outlook to 2050: by how much do land, water, and crop Yields need to increase by 2050?FAO, Rome, Italy. Pp. 4-5.

Fageria, N.K., Baligar, V.C. and Jones, C.A. 2010. Growth and Mineral Nutrition of Field Crops, third ed., New York: CRC Press; ISBN: 9781439816950

Fageria, N.K. and Stone, L.F. 2008. Micronutrient deficiency problems in South America. In: Alloway, B.J. (Ed.), Micronutrient Deficiencies in Global Crop Production. New-York: Springer.,pp. 247268.

FAO,2009. Declaration of the World Summit on Food Security, FAO, Rome, Italy.
Gaind, S. and Nain, L. 2011. Soil health in response to bio-augmented paddy-straw compost. World Journal of Agriculture Sciences7: 480-488.

Gruhan, P., Goeletti, F. and Yudelman, M. 2000. Integrated Nutrient Management, Soil Fertility and Sustainable Agriculture: Current Issues and Future Challenges. Food Agriculture and Environment Discussion Paper 32. Washington, DC, USA: International Food Policy Research Institute, 38.

Jat, L.K., Singh, S.K., Latare, A.M., Singh, R.S. and Patel, C.B. 2013. Effect of dates of sowing and fertilizer on growth and yield of wheat (Triticumaestivum) in an Inceptisol of Varanasi. Indian Journal of Agronomy 58: 611-614.

Kumar, M., Baishaya, L.K., Ghosh, D.C., Gupta, V.K., Dubey, S.K., Das, A. and Patel, D. P. 2014. Productivity and soil health of potato (Solanum tuberosum L.) field as influencedby organic manures, inorganic fertilizers and biofertilizers under high altitudes of eastern Himalayas. Journal of Agriculture science4:223-234.

Kumar, V., Tripathi, H. C. and Mishra, S. K. 2012. Impact of integrated nutrient management on yield, economics and soil fertility in hybrid rice (Oryza sativa) mustard (Brassica juncea) cropping system. New Agriculturist 23: 21-26.

Mahajan, A., Bhagat, R.M. and Gupta R.D. 2008. Integrated nutrient management in sustainable rice-wheat cropping system for food security in India. SAARC Journal of Agriculture6(2): 1-16.

Mahanta, D.K., Chandrashekara, C., Arunkumar, R., Mina, B.L.,Pandey. B.M., Mishra, P.K., Bisht, J.K. Srivastva, A.K. and Bhatt, J.C. 2013. Influence farmyard manure application and mineral fertilization on yield sustainability, carbon sequestration potential and soil property of Garden peaFrench bean cropping system in the Indian Himalayas. Scientia Horticulturae 164: 414-427.

Meena, V.S., Maurya, B.R., Bohra, J.S., Verma, R. and Meena, M.D., 2013. Effect of 
concentrate manure and nutrient levels on enzymatic activities and microbial population under submerged rice in alluvium soil of Varanasi. Field Crops Research 245: 6-12.

Mishra, J.S. and Singh, V.P. 2008. Integrated weed management in dry-seeded irrigated rice (Oryza sativa). Indian Journal of Agronomy53: 299-305.

Nas, M. and Fin, L. 2012. Integrating Nutrient Management with Diseases Management. Manila Bulletin Agriculture Magazine.pp. 1-6

Ogunwale, J. A., Olaniyan, J. O. and Aduloju, M. O. 2002. Morphological, physiochemical; and clay mineralogical properties of soils overlaying basement complex rocks in Ilorin East, Nigeria. Moor Journal of Agricultural Research3(2): 147-154.

Rahman, M.H., Islam, M.R., Jahiruddin, M., Rafii, M. Y., Hanafi, M.M., Malek, M.A. 2013.Integrated nutrient management in maize-legume-rice cropping pattern and its impact on soil fertility. Journal of Food, Agricultureand Environment11: 648-652.

Rao, A.N., Johnson, D.E., Sivaprasad, B., Ladha, J.K. and Mortimer, A.M. 2007. Weed management in direct-seeded rice. Advances in Agronomy 93: 155-257.

Savant, N.K. and De Datta, S.K. 1982. Nitrogen transformation in wetland rice soils. Advances in Agronomy 35: 241-302.

Selim, M. M. and Imhoff, S. 2020. Introduction to integrated nutrient management strategies and their contribution to yield and soil properties. International Journal of Agronomy1: 1-14.

Selim, M. 2018. Potential role of cropping system and integrated nutrient management on nutrients uptake and utilization by maize grown in calcareous soil. Egyptian Journal of Agronomy 40: 297-312.

Simarmata, T., Benny, J. and Turmuktini, T. 2011. Water Saving and Organic Fertilizers based Technology to Remediate the Health of Paddy Soils and to increase Rice productivity in Indonesia. Tropentag. University of Bonn: 5-7.

Simarmata, T., Joy, B., Sofyan, E.T., Citraresmini, A., Turmuktini, T. and Sudjana, B. 2015. Innovation of biofertilizers-organic based nutrients management and water saving technology to secure rice productivity. In: Proceeding of Tropentag Berlin, Germany.

Singh, R.S. and Ghosh, D.C. 1992. Effect of cultural practices on weed management in rainfed upland rice. Tropical Pest Management 38: 119-121.

Singh, S., Singh, G., Singh, V.P. and Singh, A.P. 2005. Effect of establishment methods and weed management practices on weeds and rice in rice-wheat cropping system. Indian Journal of Weed Science 37: 51-57.

Tirol-Padre, A., Ladha, J. K., Regmi, A. P., Bhandari, A. L. and Inubushi, K. 2007. Organic amendments affect soil parameters in two long-term rice-wheat experiments. Soil Science Society of America Journal71: 442-452.

Zhang, F., Cui, Z., Fan, M., Zhang, W., Chen, $\mathrm{X}$. and Jiang, R.2012.Integrated nutrient management for food security and environmental quality in China. Advances in Agronomy16: 1-40.

Zhang, H. L., Lal, R., Zhao, X., Xue, J. F. and Chen, F. 2014. Opportunities and challenges soil carbon sequestration by conservation agriculture in China. Advances in Agronomy124:1-36.

\section{How to cite this article:}

Bhanuwanti and Pratima Vaidya. 2020. A Review on Effect of Integrated Nutrient Management on Paddy. Int.J.Curr.Microbiol.App.Sci. 9(10): 1160-1166.

doi: https://doi.org/10.20546/ijcmas.2020.910.139 